\title{
NATIONAL WATER-QUALITY ASSESSMENT PROGRAM Island of Oahu, Hawaii
}

\section{MAJOR WATER-QUALITY ISSUES IN OAHU}

The island of Oahu NAWQA study will increase the scientific understanding of surfaceand ground-water quality and the factors that inßuence water quality. The study also will provide some of the information needed by water-resource managers to implement effective water-quality management actions and evaluate long-term changes in water quality.

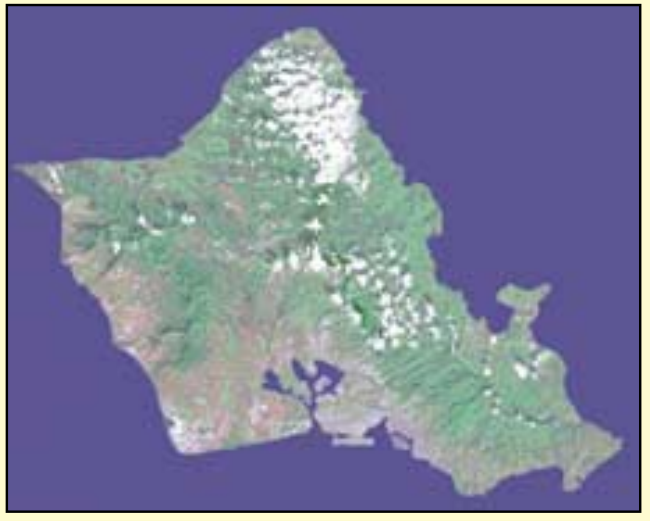

Satellite image of the island of Oahu (from SPOT Image Corporation, 1996).

Water resources are of significant economic and ecological importance to Oahu. Ground water provides essentially all municipal and domestic water for a large and expanding population, while streams provide important riparian and instream habitats for many threatened and endangered species. In addition, streams affect the physical, chemical, and aesthetic quality of receiving waters, such as estuaries, bays, and nearshore waters which are critical to the tourism-based economy of the island. The Oahu NAWQA study will describe relations among natural factors, human activities, and water-quality conditions.

\section{WHAT IS THE NATIONAL WATER-QUALITY ASSESSMENT PROGRAM?}

During the past 25 years, our Nation has sought to improve its water quality; however, many water-quality issues remain unresolved. To address the need for consistent and scientifically sound information for managing the Nation's water resources, the U.S. Geological Survey began a full-scale National Water-Quality Assessment (NAWQA) Program in 1991. This program is unique compared with other national water-quality assessment studies in that it integrates the monitoring of the quality of surface and ground waters with the study of aquatic ecosystems. The goals of the NAWQA Program are to (1) describe current water-quality conditions for a large part of the Nation's freshwater streams and aquifers, (2) describe how water quality is changing over time, and (3) improve our understanding of the primary natural and human factors affecting water quality.

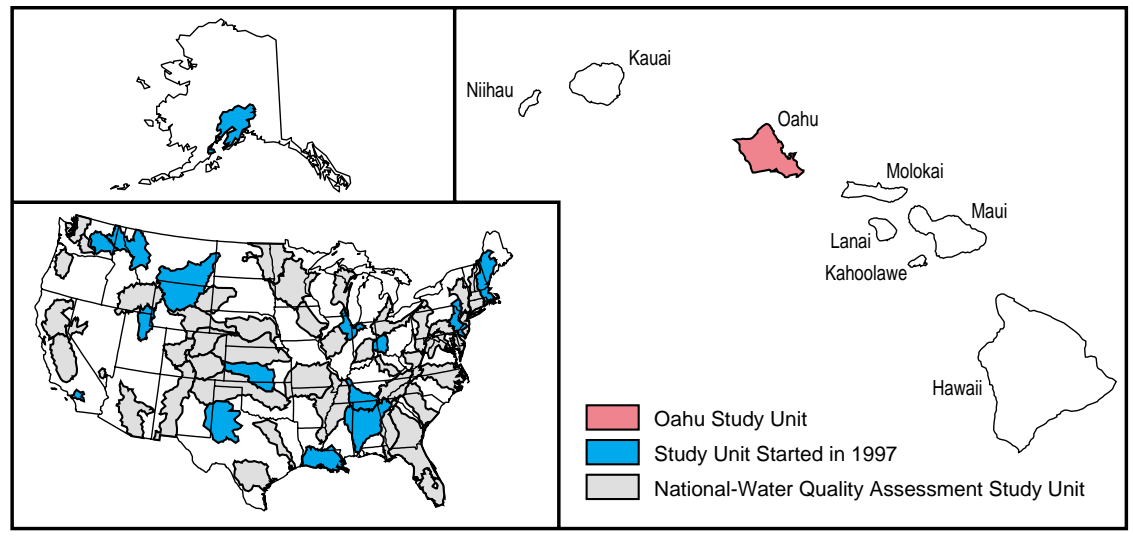

Assessing the quality of water in every location of the Nation would not be practical; therefore, NAWQA Program studies are conducted within a set of areas called study units. These study units represent the diverse geography, water resources, and land and water uses of the Nation. The island of Oahu, Hawaii, is one such study unit designed to supplement water-quality information collected in other study units across the Nation while addressing issues relevant to the island of Oahu.

Major water-quality issues in Oahu are:

- Water-use and water-quality changes expected as a result of land-use changes from large-scale sugarcane plantations to urban and small-scale diversed agriculture.

- Potential for further water-quality degradation of the principal drinking-water supply aquifer in central Oahu.

- Potential loss of native aquatic communities by degradation of riparian and instream water quality and habitat.

- Sediment and chemical loading in streams and delivery to estuaries, bays, and nearshore waters. 


\section{STUDY UNIT DESCRIPTION}

The geographic isolation of the Hawaiian islands resulted in the evolution of many endemic species. Land-use changes and introduced species have eliminated or greatly reduced the extent of many native ecosystems and resulted in the extinction of many species. Hawaii currently has the highest number of endangered species in the Nation.

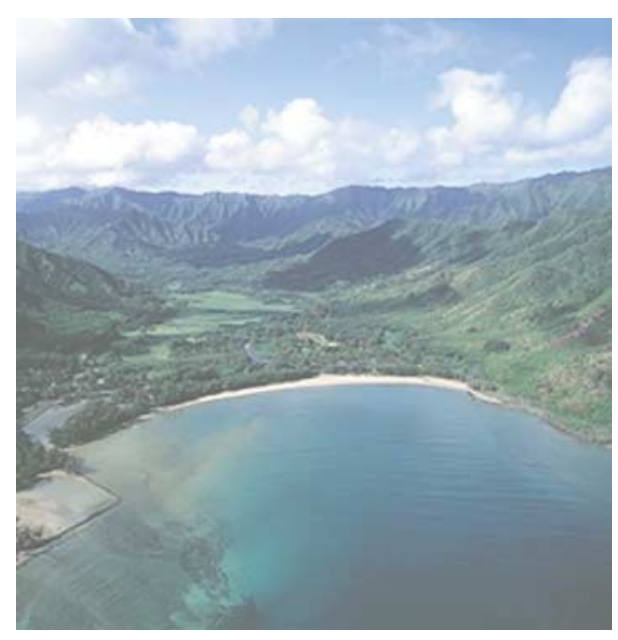

Windward Oahu--a mostly rural area where stream-water quality is critical for instream habitat of endemic species and for cultivation of taro under Native Hawaiian water rights (photo by Douglas Peebles).

Oahu (586 sq. mi.) consists of the eroded remnants of two volcanic mountain ranges, the Waianae Range and the Koolau Range. Weathering, erosion, and slope failure have modified the original domed surfaces of the volcanoes, dissecting the east and west parts of the island into a landscape of deep valleys and steep ridges. A gently sloping saddle lies between the two mountain ranges. The summit of the plateau is the approximate north-south divide for the extensive surfaceand ground-water flow systems of central Oahu. A coastal plain surrounds much of the island. Honolulu, one of the 25 largest cities in the Nation, is located in southeast Oahu.

The subtropical climate of the study unit is characterized by mild temperatures, moderate humidity, prevailing northeasterly tradewinds, and extreme variation in rainfall over short distances. Median annual rainfall is about $280 \mathrm{in} / \mathrm{yr}$ near the crest of the
Koolau Range, $80 \mathrm{in} / \mathrm{yr}$ at the summit of the Waianae Range, and 15-30 in/yr in the rainshadowed coastal lowlands of western, north-central, and south-central Oahu.

Oahu streams are important habitats for numerous species of endemic fish and invertebrates. The streams are short, with steep gradients and small drainage areas that produce flashy streamflow. In contrast, upland soils are permeable and permit rapid infiltration of water to underlying aquifers. Several large bays and estuaries receive runoff from Oahu's streams, including Pearl Harbor, Mamala Bay, Kailua Bay, Kaneohe Bay, and Waialua-Kaiaka Bay.

Land use on Oahu is classified as about 41 percent conservation, 30 percent agriculture, and 29 percent urban. The principal industry is tourism, followed by military activities and agriculture. Principal agricultural crops are pineapple and until recently sugarcane. Major land-uses are changing in central Oahu. During the past several decades, the plantation agriculture which dominated for 100 years has seen an incursion of suburban development. The resident population of Oahu, which has more than doubled since 1950, was about 871,000 in 1995. The actual population, which includes an average number of visitors to the island at any time, was about 915,000 in 1995.

Of the total freshwater used on Oahu, 326 $\mathrm{Mgal} / \mathrm{d}$ is from ground water and $71 \mathrm{Mgal} / \mathrm{d}$

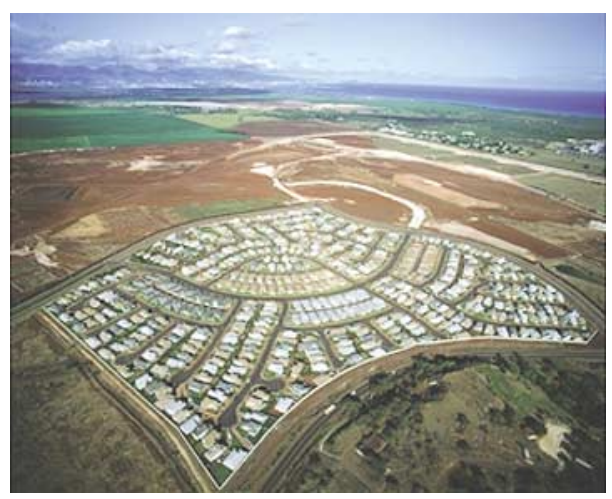

Central Oahu--an area of rapidly changing agricultural and suburban land use. The area is underlain by the island's principal drinking-water aquifer, part of which is designated a "sole source aquifer" by the USEPA in 1987 (photo by Douglas Peebles). is from surface water. Irrigation and public supply are roughly equal as the two largest freshwater uses (about $170 \mathrm{Mgal} / \mathrm{d}$ each), but a major shift in water use continues as sugarcane cultivation is replaced with diversified agriculture and urban development.

Ground water provides essentially all municipal and domestic water on Oahu. Most of the water is derived from extensive volcanic aquifers of thin-bedded basalts in central and southern Oahu. Although the depth to water is as great as 600 to $1,000 \mathrm{ft}$ in the island's interior, the aquifers are unconfined and are essentially "surficial" aquifers. Vulnerability to contamination has been confirmed by the widespread detection of pesticides and herbicides in the aquifers beneath agricultural fields, and the more localized presence of volatile organic compounds (VOC's) beneath sites of known use or spillage.

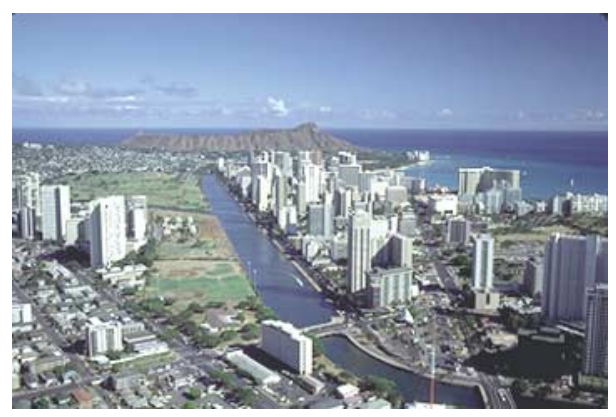

Honolulu--an urban area where runoff affects high-visibility receiving waters that include several streams, the Ala Wai Canal estuary, and nearshore waters of the major tourism center, Waikiki (photo by Douglas Peebles).

Although little surface water is consumptively used, its instream uses are important. Streams play a vital ecological role as wildlife habitat and as conveyors of runoff to estuaries, bays, and nearshore coastal waters. Stream waters have recreational and aesthetic value to residents and visitors alike, and a steady supply of cool stream water is necessary for cultivation of taro, the traditional staple of Native Hawaiians. 


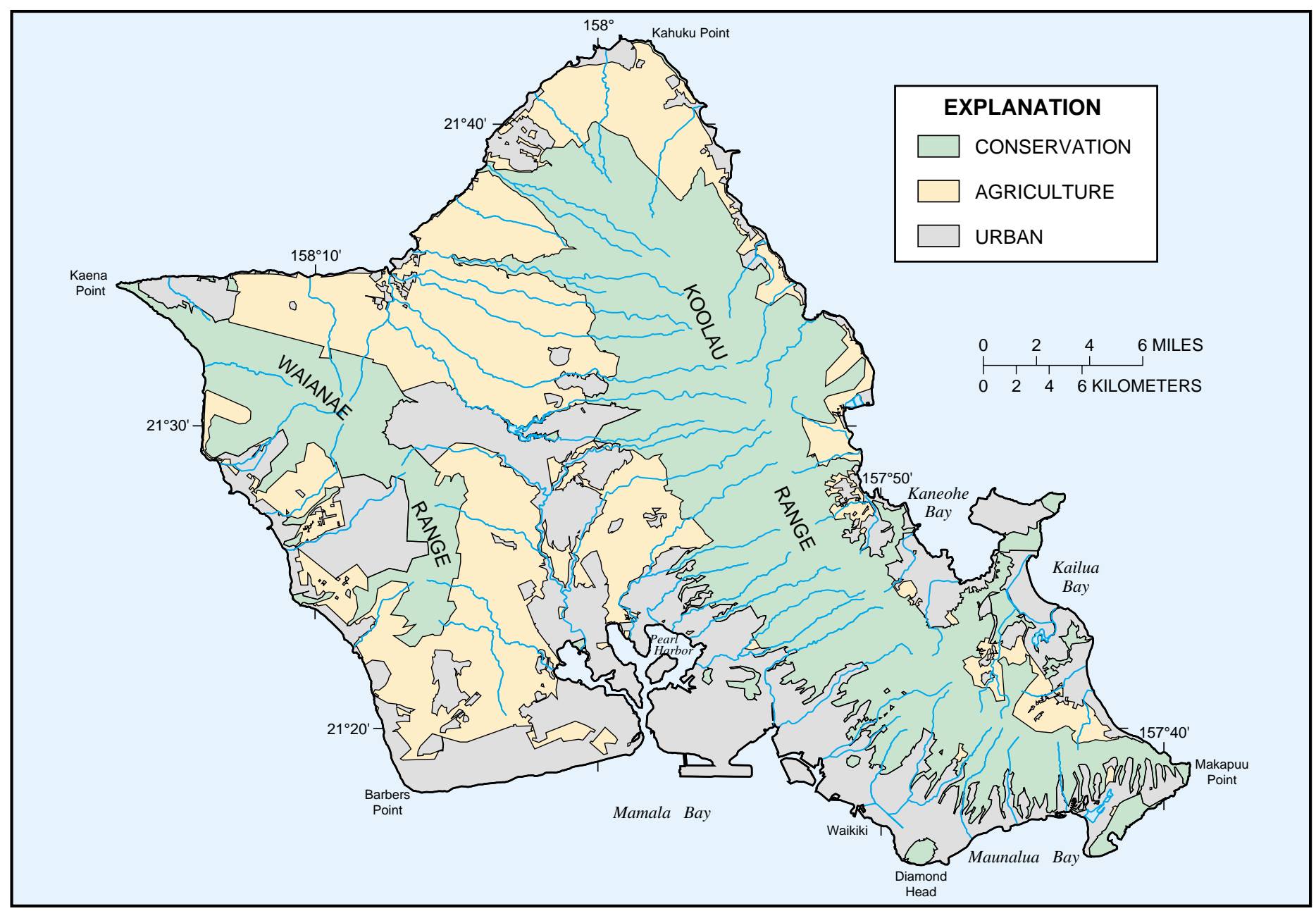

Land-use classification, island of Oahu, 1996 (modified from City and County of Honolulu, Department of Land Utilization).

\section{SchedULE OF STUdY ACTIVITIES}

The island of Oahu study is one of several NAWQA studies that began in Federal fiscal year 1997 (October 1996). Study planning and design, and analysis of existing data will be done during the first 2 years, which is consistent in all NAWQA studies. After the 2-year planning period, surface- and groundwater and biological data are collected intensively for 3 years (termed the highintensity phase). A low-intensity phase follows for 6 years, during which water quality is monitored at a selected number of sites and areas assessed during the highintensity phase. This combination of high- and low-intensity-monitoring phases allows the NAWQA Program to examine trends in water quality over time.

During the planning period, existing data and results from previous studies are

reviewed to understand the primary physical, chemical, and biological factors that affect water quality in the study unit and to identify gaps in the current data. Descriptions of how land use and land cover, soils, geology, physiography, climate, and drainage characteristics may influence water quality are to be included in technical and nontechnical reports. Information obtained from reviews of previous studies, along with field checks of existing monitoring stations

\begin{tabular}{|c|c|c|c|c|c|c|c|c|c|c|c|c|c|c|}
\hline Activity & 용 & ஓ & ᄋ & ర్ & ్ㅗㅇ & ণิ & గ్రి & ষ্ণ & 옹 & ๕్ & స్ํำ & ᄋ్ & 옹 & 응 \\
\hline $\begin{array}{l}\text { Planning and } \\
\text { study design }\end{array}$ & & & & & & & & & & & & & & \\
\hline $\begin{array}{c}\text { High intensity } \\
\text { monitoring }\end{array}$ & & & & & & & & & & & & & & \\
\hline Reports & & & & & & & & & & & & & & \\
\hline $\begin{array}{c}\text { Low intensity } \\
\text { monitoring }\end{array}$ & & & & & & & & & & & & & & \\
\hline
\end{tabular}

and candidate sampling sites, and field reconnaissance data, are used to design a sampling program for the study unit.

During the high-intensity phase, new chemical, physical, and biological data are collected for selected areas at local and regional scales to describe the quality of water throughout the study unit.

Measurements are made to determine water chemistry in streams and aquifers; the quantity of suspended sediment and the quality of bottom sediments in streams; the variety and number of fish, benthic invertebrates, and algae in streams; and the presence of contaminants in fish tissues. Individual streams and aquifers, chemical constituents, and biological species are selected for sampling to represent the important water resources and water-quality concerns in the study unit and the Nation. A series of technical and nontechnical reports describing results of high- and low-intensityphase data collection and analysis are planned. 


\section{AsSESSING WATER QUALITY IN THE OAHU STUDY UNIT}

The NAWQA Program is designed to assess the status of and trends in the quality of the Nation's ground- and surface-water resources and to link the status and trends with an understanding of the natural and human factors that affect the quality of water. The design of the Program balances the unique assessment requirements of individual study units with a nationally consistent design and data-collection structure that incorporates a multiscale, interdisciplinary approach. Surface- and ground-water studies are done at local (a few square miles to hundreds of square miles) and, for most study units, regional (thousands of square miles) scales to understand the water-quality conditions and issues.

An Occurrence and Distribution Assessment is the largest and most important component of the first intensive study phase in each study unit. The goal of the Occurrence and Distribution Assessment is to characterize, in a nationally consistent manner, the broad-scale geographic and seasonal distributions of water-quality conditions in relation to major contaminant sources and natural background conditions. The following discussions describe the typical surface- and ground-water monitoring components of the Occurrence and Distribution Assessment. The Oahu NAWQA study will have a similar design.

Surface Water. The national study design for surface waters focuses on water-quality conditions in streams using three interrelated components Ñwater-column studies, bedsediment and fish-tissue studies, and ecological studies. Water-column studies monitor physical and chemical characteristics, which include suspended sediment, major ions, nutrients, organic carbon, and dissolved pesticides, and their relation to hydrologic conditions, sources, and transport. Most surface water is monitored at sites termed either basic-fixed sites or intensive-fixed sites, according to the frequency of the sampling. The sampling sites are selected to determine the quality of water in relation to important environmental settings in the study unit. Most NAWQA study units have 8-10 basic-fixed and 2-3 intensive-fixed sites. Basic-fixed sites are sampled monthly and at high-flows for 2 years of the 3-year high-intensity phase. The intensive-fixed sites are monitored more frequently (as often as weekly during key time periods) for at least 1 year, to characterize short-term variations of water quality. Basic-fixed or intensive-fixed sites can be either indicator or integrator sites. Indicator sites represent relatively homogeneous, small basins (generally less than 100 square miles) associated with specific environmental settings, such as a particular land use that substantially affects water quality in the study unit. Integrator sites are established at downstream points in larger relatively heterogeneous drainage basins with complex combinations of landuse settings. Indicator sites are typically located in the drainage basins of integrator sites. Water samples are also collected as part of synoptic (short-term) investigations of specific water-quality conditions or issues during a specific hydrologic period (for example during low streamflow) to provide greater spatial coverage and to allow investigators to assess whether the basicfixed or intensive-fixed sites are representative of streams throughout the study unit. Bed-sediment and fish-tissue studies assess trace elements and hydrophobic organic contaminants at 15-20 sites to determine their occurrence and distribution.

Ecological studies evaluate the relations among physical, chemical, and biological characteristics of streams. Aquatic biological communities at the basic- and intensivefixed sites are surveyed during the 3 years of the high-intensity-sampling phase. These surveys are done along a delineated stream reach and include a habitat assessment of the site and annual surveys of the fish, algal, and benthic invertebrate communities.

Additionally, ecological sampling may be integrated with surface water synoptic studies to provide greater spatial coverage and to assess whether the biological communities at basic- and intensive-fixed sites are representative of streams throughout the study unit.

Ground Water. The national study design for ground water focuses on waterquality conditions in major aquifers, with emphasis on recently recharged ground water associated with present and recent human activities, by using study-unit surveys, land-use studies, and flowpath studies. Ground-water samples are analyzed for major ions, nutrients, pesticides, volatile organic compounds, and trace elements. Study-unit surveys are used to assess the water quality of the major aquifer systems of each study unit. About 20-30 existing wells are randomly selected to be sampled in each of 2-3 aquifer subunits. Land-use studies focus on recently recharged shallow aquifer systems so that the influences of land-use practices and natural conditions can be assessed. Typically, about 20-30 new observation wells are randomly located within each land use and aquifer type. Results from the 2-4 land-use studies typically performed can be compared with results from the general study-unit survey to determine the effect of particular land uses on ground-water quality. Flow-path studies use transects and groups of clustered, multilevel observation wells to examine specific relations among land-use practices; ground-water flow; occurrence and transport of contaminants, and interactions between ground and surface water.

\section{Communication AND COORDINATION}

Communication and coordination between the U.S. Geological Survey and other scientific and land- and watermanagement organizations are critical components of the NAWQA Program. A successful study depends on the advice, cooperation, and information from many Federal, State, regional, and local agencies, and the public concerned about water resources. The Oahu NAWQA study unit will establish and maintain a liaison committee that includes representatives from agencies and organizations that have water-resource responsibilities and interests. Committee activities include the exchange of information about regional and local water-quality issues, identification of sources of data and information, assistance in site selection and in the design and scope of study products, and the review of study planning documents and reports.

\section{SUGGESTIONS FOR FURTHER READING}

Gilliom, R.J., Alley, W.M., and Gurtz, M.E.,1995, Design of the National WaterQuality Assessment Program: Occurrence and distribution of water-quality conditions: U.S. Geological Survey Circular 1112, 33 p.

Leahy, P.P., Rosenshein, J.S., and Knopman, D.S., 1990, Implementation plan for the National Water-Quality Assessment Program: U.S. Geological Survey OpenFile Report 90-174, 10 p.

\section{FOR MORE INFORMATION}

Information on technical reports and hydrologic data related to the island of Oahu study unit and the NAWQA Program can be obtained from:

Stephen S. Anthony, Oahu NAWQA Chief

U.S. Geological Survey

677 Ala Moana Blvd., Suite 415

Honolulu, HI 96813

(808) 522-8290

Internet: http://water.usgs.gov

By: Stephen S. Anthony

USGS Fact Sheet FS-006-98 March 1998 